\title{
SUBSTITUSI BUNGKIL KEDELAI DENGAN DDGS (Distillers Dried Grains and Solubles) TERHADAP KANDUNGAN LEMAK KASAR DAN ENERGI DAGING IKAN NILA MERAH (Oreochromis niloticus)
}

\section{SUBSTITUTION OF SOYBEAN MEAL WITH DDGS (Distillers Dried Grains and Solubles) CONTENT OF CRUDE FAT AND ENERGY MEAT RED TILAPIA (Oreochromis niloticus)}

\author{
Sathiul Inayah, Agustono dan M. Anam Al Arif
}

Fakultas Perikanan dan Kelautan Universitas Airlangga

Kampus C Mulyorejo - Surabaya, 60115 Telp. 031-5911451

\begin{abstract}
Red tilapia (O. niloticus) is a food fish including efforts to increase the commodity into aquaculture production in 2014 amounted to 353\%. To support efforts to increase production, so it needed one attempt that the cultivation of tilapia. One effort to reduce the cost of feed needed alternative feed ingredients were good quality. One of the alternatives that are cheap and high nutritional value is DDGS. DDGS is a byproduct from dry milling ethanol industry. Although the by-product of milling corn and the price is cheaper than soybean meal but the nutritional content is similar to soybean meal. From the results of the proximate analysis of DDGS contains $28 \%$ protein, $17 \%$ fat, $10 \%$ crude fiber, $27 \%$ and energy BETN $3150 \mathrm{kcal} / \mathrm{kg}$. The results showed that the use of DDGS as a substitute for soybean meal until $80 \%$ did not cause significant differences ( $p>0.05$ ) on crude fat and energy content of meat red tilapia (O.niloticus).
\end{abstract}

Keywords : $O$. niloticus, soybean meal, Distillers Dried Grains and Solubles

\section{Pendahuluan}

Ikan nila merah (Oreochromis niloticus) merupakan ikan konsumsi yang digemari masyarakat dan termasuk komoditas yang menjadi upaya peningkatan produksi perikanan budidaya pada tahun 2014 sebesar $353 \%$ (Kementerian Kelautan dan Perikanan, 2010). Untuk mendukung upaya peningkatan produksi tersebut maka diperlukan usaha salah satunya yaitu dengan budidaya ikan nila. Budidaya merupakan salah satu usaha untuk meningkatkan produksi. Pakan ikan merupakan salah satu faktor yang menentukan keberhasilan suatu budidaya perikanan (Bambang, 2001).

Untuk mendukung kegiatan tersebut sebagaimana diketahui bahwa dalam budidaya ikan $60-70 \%$ biaya produksi dipergunakan untuk biaya pakan (Anggraeni dkk., 2010). Salah satu bahan pakan yang mahal adalah bungkil kedelai. Harga bungkil kedelai impor dipasaran mencapai Rp. $9.000-10.000$ per kg sedangkan harga kedelai lokal berkisar Rp. 8.000 per $\mathrm{kg}$ meskipun kualitasnya dinilai tidak sebaik kedelai impor (BPS, 2012). Salah satu upaya untuk mengurangi biaya pakan dibutuhkan bahan pakan alternatif yang berkualitas baik (Bidura, 2005). Salah satu bahan alternatif yang murah dan bernilai gizi tinggi adalah DDGS (Distillers Dried Grains and Solubles). DDGS merupakan produk ikutan (sampingan) dari penggilingan kering dan industri etanol (Tangendjaja, 2008). Meskipun hasil samping dari penggilingan jagung dan harganya lebih murah daripada bungkil kedelai tetapi kandungan nutrisinya hampir sama dengan bungkil kedelai. Dari hasil analisis proksimat DDGS mengandung protein $28 \%$, lemak $17 \%$, serat kasar $10 \%$, BETN $27 \%$ dan energi $3150 \mathrm{kkal} / \mathrm{kg}$ (ULPKP, 2012).

Kebutuhan nutrisi pada pakan ikan nila (O. niloticus) sebesar $25-30 \%$ protein, $4-10$ $\%$ lemak dan energi 2500 - $4300 \mathrm{kkal} / \mathrm{kg}$ (BBAT Sukabumi, 2005 dalam Indariyanti, 2011). Kandungan lemak dan energi metabolizable dalam DDGS melebihi kandungan lemak dan energi dari bungkil kedelai yaitu sebesar $17 \%$ dan $3150 \mathrm{kkal} / \mathrm{kg}$. Kebutuhan lemak bagi ikan akan digunakan untuk membantu proses metabolisme dan menjaga keseimbangan daya apung ikan dalam air serta memelihara bentuk dan fungsi membran atau jaringan. Lemak yang berlebih dapat disimpan sebagai cadangan energi untuk kebutuhan energi jangka panjang selama melakukan aktivitas (Watanabe, 1988). Dari latar belakang ini, maka dilakukan penelitian substitusi bungkil kedelai dengan DDGS untuk mengetahui pengaruh substitusi bungkil kedelai dengan DDGS terhadap kandungan lemak kasar 
dan energi daging ikan nila merah (O. niloticus) melalui serangkaian uji analisis proksimat.

Tujuan dari penelitian ini adalah untuk mengetahui perbedaaan kandungan lemak kasar dan energi dalam daging ikan nila merah $(O$. niloticus) pada perlakuan pakan substitusi bungkil kedelai dengan DDGS (Distillers Dried Grains and Solubles).

Penelitian ini diharapkan dapat memberikan informasi bagi mahasiswa dan masyarakat perikanan mengenai pengaruh penggunaan DDGS (Distillers Dried Grains and Solubles) sebagai bahan pakan ikan alternatif pengganti bungkil kedelai terhadap kandungan lemak dan energi daging ikan nila merah (O. niloticus).

\section{Metodologi}

Penelitian ini akan dilakukan di Fakultas Perikanan dan Kelautan Universitas Airlangga. Analisis proksimat bahan baku pakan dilakukan di Unit Layanan Pemeriksaan Laboratoris, Konsultasi dan Pelatihan Fakultas Kedokteran Hewan Universitas Airlangga.

Peralatan yang digunakan dalam penelitian ini meliputi : pisau, kantong plastik ukuran $5 \mathrm{~kg}$, baki, timbangan, spuit, gelas ukur. Bahan penelitian ikan nila merah yang telah diberi pakan buatan yaitu substitusi bungkil kedelai dengan Distillers Dried Grains And Solubles (DDGS) dan bahan kimia untuk analisis lemak kasar dan energi.

Penelitian ini menggunakan metode eksperimental yang bertujuan untuk mengetahui perbedaaan jumlah lemak kasar dan energi dalam daging ikan nila merah (O. niloticus) pada perlakuan formulasi pakan substitusi bungkil kedelai dengan DDGS (Distillers Dried Grains And Solubles).

Prosedur Kerja

A. Persiapan Ikan Uji

Ikan nila merah didapatkan dari Balai Pengembangan Budidaya Air Tawar (BPBAT) Umbulan. Ikan yang digunakan dalam penelitian ini adalah ikan nila merah $(O$. niloticus) yang berumur 1 bulan dengan bobot rata-rata 6 gram dengan panjang $6-7 \mathrm{~cm}$. Ikan nila yang digunakan dalam penelitian ini adalah ikan yang sehat, tidak terserang penyakit dan homogen.

B. Persiapan Akuarium dan Air Media Pemeliharaan

Persiapan penelitian meliputi persiapan akuarium dan air media pemeliharaan. Akuarium yang akan digunakan dalam penelitian ini disterilisasi terlebih dahulu dengan menggunakan klorin 400 ppm kemudian dibilas dengan menggunakan air bersih dan dikeringkan (Balai Budidaya Laut, 2003). Media pemeliharaan yang digunakan dalam penelitian ini adalah air tawar. Air tawar tersebut dimasukkan ke dalam 20 akuarium. Tiap akuarium diisi dengan air 10 liter.

C. Pelaksanaan Penelitian

Bahan penyusun pakan dianalisis proksimat terlebih dahulu untuk mengetahui kandungan nutrisinya. Kemudian pakan disusun sesuai dengan takaran yang telah ditentukan. Setelah disusun sesuai dengan takaran yang telah ditentukan, pakan uji dibuat dalam bentuk pelet dan ukurannya disesuaikan dengan bukaan mulut ikan uji. Hasil pembuatan pelet kemudian dianalisis proksimat.

Ikan nila merah ditempatkan di akuarium. Terdapat 5 perlakuan, setiap perlakuan menggunakan 4 akuarium. Masingmasing akuarium diisi ikan dengan padat tebar 1 ekor/ 2 liter. Sebelumnya ikan diadaptasikan terlebih dahulu selama 7 hari dengan tujuan adaptasi lingkungan yang baru dan beradaptasi dengan pakan uji supaya ikan mau makan sewaktu dilaksanakan penelitian. Setelah masa adaptasi selesai, ikan dipuasakan selama 24 jam dengan tujuan untuk menghilangkan pengaruh sisa pakan dalam tubuh ikan.

Media pemeliharaan berupa air tawar. Air tersebut ditempatkan di dalam akuarium berukuran $40 \times 20 \times 25 \mathrm{~cm}^{3}$ sebanyak 10 liter/akuarium. Kualitas air pada media pemeliharaan dijaga agar kondisinya tetap baik dengan melakukan penyiponan kotoran sisa pakan dalam akuarium setiap hari. Penyiponan ini sekaligus mengganti air sebanyak $50 \%$ dari air sebelumnya. Air baru yang ditambahkan berasal dari bak tandon. Air tandon berasal dari PDAM yang diendapkan selama 24 jam. Sebelum pakan tersebut diberikan, dilakukan penimbangan berat ikan uji untuk menentukan jumlah pakan yang akan diberikan. Nugroho dan Kristanto, (2008) menyatakan bahwa pemberian pakan diberikan tiga kali sehari sebanyak 3\% dari keseluruhan berat tubuh ikan uji. Pemberian pakan dilakukan pada pukul 08.00, 12.00 dan 16.00 WIB. Berat ikan pada akhir pemeliharaan dicatat dan dihitung. Setelah pemeliharaan akhir ikan dibunuh dengan tujuan menghentikan aktifitas dan dilanjutkan dengan pemisahan daging dengan tubuh ikan / pemfilletan. Daging yang telah diperoleh kemudian dihancurkan dan dilakukan serangkaian analisis proksimat.

Parameter Penelitian

Parameter pada penelitian ini adalah kadar lemak kasar dan energi daging ikan nila 
merah. Kadar lemak kasar (LK) dan energi dapat dihitung dengan rumus sebagai berikut:

$$
\text { Lemak kasar }=\frac{\text { Berat lemak kasar }}{\text { Berat awal sampel }} \times 100 \%
$$

$$
\begin{aligned}
\text { Energi }= & \{(\% \text { Protein x Koef Energi Protein })+ \\
& (\% \text { Lemak x Koef Energi Lemak })+(\% \\
& \text { SK x Koef Energi SK })+(\% \text { BETN x } \\
& \text { Koef Energi BETN })\} \times 10
\end{aligned}
$$

Analisis Statistik

Analisis statistik menggunakan Analysis of Varian (ANOVA) yaitu RAL (Rancangan Acak Lengkap) untuk mengetahui pengaruh perlakuan. Apabila dari analisis ragam diketahui bahwa perlakuan menunjukkan pengaruh yang berbeda nyata atau berbeda sangat nyata, maka untuk membandingkan pengaruh perlakuan dilanjutkan Uji Jarak Berganda Duncan pada tingkat kepercayaan $5 \%$ (Kusriningrum, 2008).

\section{Hasil dan Pembahasan}

Rata-rata kandungan lemak kasar berdasarkan bahan kering dalam daging ikan nila merah yang telah diberi pakan substitusi DDGS (Distillers Dried Grains and Solubles) pada bungkil kedelai menunjukkan bahwa semakin tinggi substitusi DDGS pada bungkil kedelai akan diikuti semakin tingginya kandungan lemak kasar pada daging ikan nila merah (Oreochromis niloticus).

Analisis statistik terhadap kandungan lemak kasar daging ikan nila merah (Oreochromis niloticus) yang diberi pakan substitusi DDGS (Distillers Dried Grains and Solubles) pada bungkil kedelai menunjukkan rata-rata kandungan lemak kasar berdasarkan bahan kering tidak menyebabkan perbedaan yang nyata $(\mathrm{p}>0.05)$ pada seluruh perlakuan (Tabel 1).

Tabel 1. Rata-rata kandungan lemak kasar berdasarkan bahan kering pada substitusi bungkil kedelai dengan DDGS (Distillers Dried Grains and Solubles) dalam daging ikan nila merah (Oreochromis niloticus).

\begin{tabular}{|c|c|c|}
\hline $\begin{array}{c}\text { Per- } \\
\text { lakuan }\end{array}$ & $\begin{array}{c}\text { Kandungan } \\
\text { Lemak Kasar }(\%) \\
\mathrm{X} \pm \mathrm{SD}\end{array}$ & $\begin{array}{c}\text { Transformasi } \\
(\sqrt{\mathrm{y}}) \\
\mathrm{X} \pm \mathrm{SD}\end{array}$ \\
\hline P1 & $4.4142 \pm 3.2456$ & $2.0097 \pm 0.7074$ \\
P2 & $6.4466 \pm 2.4421$ & $2.5024 \pm 0.4960$ \\
P3 & $7.2298 \pm 2.9251$ & $2.6417 \pm 0.5788$ \\
P4 & $7.2776 \pm 2.5292$ & $2.6598 \pm 0.5203$ \\
P5 & $8.8113 \pm 3.7736$ & $2.9220 \pm 0.6037$ \\
\hline
\end{tabular}

Rata-rata kandungan energi berdasarkan bahan kering dalam daging ikan nila merah yang telah diberi pakan substitusi DDGS (Distillers Dried Grains and Solubles) pada bungkil kedelai menunjukkan bahwa semakin tinggi substitusi DDGS pada bungkil kedelai menyebabkan peningkatan kandungan energi pada daging ikan nila merah (Oreochromis niloticus)

Analisis statistik terhadap kandungan energi daging ikan nila merah (Oreochromis niloticus) yang diberi pakan substitusi DDGS (Distillers Dried Grains and Solubles) pada bungkil kedelai menunjukkan rata-rata kandungan energi berdasarkan bahan kering tidak menyebabkan perbedaan yang nyata ( $>0.05$ ) pada seluruh perlakuan (Tabel 2).

Tabel 2. Rata-rata kandungan energi berdasarkan bahan kering pada substitusi bungkil kedelai dengan DDGS (Distillers Dried Grains and Solubles) dalam daging ikan nila merah (Oreochromis niloticus).

\begin{tabular}{|c|c|}
\hline Perlakuan & $\begin{array}{c}\text { Kandungan Energi }(\mathrm{kkal} / \mathrm{kg}) \\
\mathrm{X} \pm \mathrm{SD}\end{array}$ \\
\hline P1 & $3049.1512 \pm 134.5931$ \\
P2 & $3081.5481 \pm 276.1945$ \\
P3 & $3113.3798 \pm 93.8358$ \\
P4 & $3132.7339 \pm 50.2485$ \\
P5 & $3229.0991 \pm 177.3775$ \\
\hline
\end{tabular}

Lemak adalah golongan lipida (latin yaitu lipos yang artinya lemak). Lipida larut dalam pelarut nonpolar dan tidak larut dalam air. Sifat kelarutan ini yang membedakan lipida dengan golongan senyawa lain seperti protein dan karbohidrat yang pada umumnya tidak larut dalam pelarut nonpolar (Hart, 1990).

Berdasarkan Analisis Statistik substitusi bungkil kedelai dengan DDGS (Distillers Dried Grains and Solubles) tidak menyebabkan adanya perbedaan yang nyata pada kandungan lemak kasar daging ikan nila merah pada seluruh perlakuan. Hal ini disebabkan karena kandungan lemak dalam ransum pakan masih dalam kisaran kebutuhan ikan terhadap lemak. Kandungan lemak dalam ransum pakan sesuai dengan kebutuhan ikan yaitu sebesar 4,83 sampai 8,74 \%. Menurut Nugroho dan Kristanto (2008), ikan nila dapat menerima pellet berkadar protein $25-35 \%$, lemak $4-10 \%$, karbohidrat $25 \%$ dengan pemberian pakan sebanyak $3-5 \%$ perbobot biomassa dengan frekuensi pemberian pakan 3 5 kali sehari.

Juju (2004) menyatakan bahwa akumulasi total lemak tubuh dan penyebarannya 
pada bagian - bagian tubuh ikan dipengaruhi oleh pakan. Komposisi pakan merupakan faktor yang mempengaruhi kandungan lemak tubuh. Pembentukan lemak tubuh pada ikan terjadi karena adanya kelebihan energi yang dikonsumsi. Energi yang digunakan tubuh umumnya berasal dari karbohidrat dan cadangan lemak. Sumber karbohidrat mampu memproduksi lemak tubuh yang disimpan di sekeliling organ dalam dan dibawah kulit (Setiawan dan Sujana, 2009).

Nilai energi bahan pakan atau ransum dapat dinyatakan dalam bentuk energi bruto, energi dapat dicerna, energi metabolis dan energi netto. Energi bruto adalah jumlah panas yang dilepaskan jika suatu zat mengalami oksidasi sempurna menjadi karbondioksida dan air dalam bomb calorimeter dengan tekanan 2530 atmosfer oksigen, energi tercerna adalah energi bruto bahan pakan atau ransum dikurangi dengan energi bruto feses. Energi metabolis adalah energi bruto bahan pakan atau ransum dikurangi energi bruto feses, urin dan gas yang dihasilkan selama proses pencernaan (NRC, 1994).

Berdasarkan Analisis Statistik substitusi bungkil kedelai dengan DDGS (Distillers Dried Grains and Solubles) tidak menyebabkan adanya perbedaan yang nyata pada kandungan energi daging ikan nila merah pada semua perlakuan. Hal ini disebabkan karena kandungan energi dalam ransum pakan masih dalam kisaran kebutuhan ikan terhadap energi. Kandungan energi dalam ransum pakan sesuai dengan kebutuhan ikan yaitu sebesar 2430,23 - 2527,29 kkal/kg. Menurut BBAT Sukabumi (2005) dalam Indariyanti (2011) menyatakan bahwa kebutuhan energi pada pakan ikan nila yaitu sebesar 2500 - 4300 $\mathrm{kkal} / \mathrm{kg}$.

Energi yang berlebihan akan disimpan sebagai lemak. Kelebihan energi metabolis tidak dikeluarkan oleh tubuh hewan. Oleh karena itu, paling efisien dalam pemberian pakan pada ikan adalah membuat ransum seimbang antara tingkat energi dan zat - zat pakan yang lainnya (Wahju, 2004).

\section{Kesimpulan}

Penggunaan DDGS (Distillers Dried Grains and Solubles) sebagai substitusi bungkil kedelai sampai $80 \%$ dari bungkil kedelai tidak menyebabkan adanya perbedaan yang nyata ( $p>0.05)$ terhadap kandungan lemak kasar dan energi daging ikan nila merah (Oreochromis niloticus).

DDGS (Distillers Dried Grains and Solubles) dapat digunakan sebagai pengganti bungkil kedelai sampai taraf $80 \%$ dengan tidak mempengaruhi kandungan lemak kasar dan energi untuk mengurangi biaya pembuatan pakan ikan nila merah (Oreochromis niloticus).

\section{Daftar Pustaka}

Almatsier, S, 2002. Prinsip Dasar Ilmu Gizi. Gramedia Pustaka Utama, Jakarta.

Abbas, S. 1995. Pakan Ikan Alami. Kanisius. Yogyakarta. 87 hal.

Anggraeni, H. S., R. R. P. Fasa dan U. K. Alma'rufah. 2010. Inovasi Pengolahan Limbah Tepung (Ampas Ketela) Menjadi Pelet Sebagai Makanan Alternatif pada Ikan. http://community. um.ac.id. 27 Agustus 2010. 10 hal.

Arie, U. 1999. Pembenihan dan Pembesaran Nila Gift. Penebar Swadaya.Jakarta.

Badan Pusat Statistik. 2012. Indikator Pertanian: Agriculture Indikators.BPS. Jakarta.

Bambang Riyanto.2001, Dasar-Dasar Pembelanjaan Perusahaan; Cet.7,BEP, Yogyakarta.

BBL (Balai Budidaya Laut). Direktorat Jenderal Perikanan Budidaya Departemen Kelautan Dan Perikanan. 2003. Penanganan Penyakit Ikan Budidaya Laut. ISBN : 979-98017-1-0. No : 12. Lampung. hal. 24.

Bidura, I. G. N. G. 2005. Penyediaan Pakan Unggas. Buku Ajar Jurusan Nutrisi dan Makanan Ternak Fakultas Peternakan Universitas Udayana. Denpasar.

Boniran, S. 1999. Quality control untuk bahan baku dan produk akhir pakan ternak. Kumpulan Makalah Feed Quality Management Workshop. American Soybean Association dan Balai Penelitian Ternak. hlm. 2-7.

Djajasewaka, H. 1985. Pakan Ikan. Yasaguna. Jakarta.

Effendie, 2002. Biologi Perikanan. Yayasan Pustaka Nusantara Yogyakarta.

Erickson, G.E., T.J. Klopfenstein, D.C. Adams and R.J. Rasby. 2006. Utilization of Corn Co-Products in the Beef Industry. Nebraska Corn Board and the University of Nebraska. www.nebraskacorn.org. 17 p.

Gusrina, 2008. Budidaya Ikan untuk SMK. Pusat Perbukuan Departemen Pendidikan Nasional. Jakarta.

Harris, R.S. dan E. Karmas. 1989. Evaluasi Gizi pada Pengolahan Bahan Pangan. Penerbit ITB. Bandung

Hartadi. H., Soedomo. R., Soekanto, L. dan A .D. Tillman. 1980 . Tabel-tabel dari 
Komposisi Bahan Makanan Untuk Indonesia . Fakultas Peternakan Universitas Gajah Mada . Program EFD. Yayasan Rockefeller, Yogyakarta.

Hertrampf J.W., Pascual F.P., 2000. Handbook Ingredients for Aquaculture Feeds. Kluwer Academic Publisher. London. pp. 100-104.

Hidayat, N., Masdiana, Padaga dan S. Suhartini. 2006. Mikrobiologi Industri. Andi Offset. Yogyakarta. Hal 15-31.

Hutagalung, R.I. 1999. Definisi dan Standar Bahan Baku Pakan. Kumpulan Makalah Feed Quality Management Workshop American Soybean Association dan Balai Penelitian Ternak. hlm. 2-13.

Indariyanti, N. 2011. Evaluasi Kecernaan Campuran Bungkil Inti Sawit Dan Onggok Yang Difermentasi Oleh Trichoderma harzianum Rifai Untuk Pakan Nila Oreochromis sp. Tesis. Pascasarjana. Institut Pertanian Bogor. Bogor. hal 17.

Isnaeni.M.2006. Pertanian Organik.Cetakan Pertama.Yogyakarta : Penerbit Kreasi. Wacana.Khairuman dan K. Amri. 2002. Membuat Pakan Ikan Konsumsi. Agromedia Pustaka. Jakarta. 45 hal.

Juju, W. 2004. Ilmu Nutrisi Unggas edisi ke-5. Gadjah Mada University Press. Yogyakarta.

Julisti, B. 2010. Pengenalan Alat Dan Analisis Tingkat Kekeruhan Air Dengan Turbidimeter. http:// http://btagallery. blogspot.com. [Diakes pada 16 Mei 2011].

Khairuman dan K. Amri. 2008. Budidaya Ikan Nila Secara Intensif. Agromedia Pustaka. Jakarta. hal 7.

Kaushik, S. and F, Medale. 1995. Energy Requirement, Utilization and Dietary Supply to Salmonids Aquaculture, 124:81-97.

KKP. 2010. Kelautan dan perikanan dalam angka 2009. Kementerian Kelautan dan Perikanan, Jakarta.

Kusriningrum. 2008. Perancangan Percobaan. Airlangga University Press. Surabaya.

Lehninger AL. 1990. Dasar-dasar Biokimia. Maggy Thenawidjaja, penerjemah. Jakarta: Penerbit Erlangga. Terjemahan dari: Principles of Biochemistry.

Lovell, T. 1998. Nutrition and Feeding of Fish. Second Edition. Kluwer Academic Publisher. USA.
Mahyuddin, K. 2008. Panduan Lengkap Agribisnis Lele. Jakarta : Penebar Swadaya.

Mcdonald, P., R.A Edwards, J.F.D. Greenhalg, C.A. Morgan. 1995. Animal Nutrition, 5th Edition. John Wiley \& Sons inc., New York.

National Research Council. 1993. Nutrient Requirement of Warmwater fishes. Sub Committee on Warmwater Fish Nitrition. Committee on Animal Nutrition. Board on Agriculture and Renewable Resources. National Academy Science. Washington, DC. $78 \mathrm{p}$.

Nugroho, E. dan A. H. Kristanto, 2008. Panduan Lengkap Ikan Konsumsi Air Tawar Populer. Penebar Swadaya. Jakarta. Hal 67-72.

Panggabean, A. 2009. Budidaya Ikan Nila (Oreochromis niloticus). Departemen Kehutanan. Fakultas Pertanian. Sumatra Utara. Hal. $2-8$; 12-14.

Rasidi. 2002. Formulasi Pakan Lokal Alternatif untuk Unggas. Cetakan 5. Penebar Swadaya. Jakarta. 106 hal.

Rostika, Rita dan Setyogati Widy, 2006. Mk Nutrisi Ikan Prodi Perikanan Fpik UNPAD. Bahan Tambahan Dalam Pakan Ikan.

Saade, E., 2009. Bahan Bacaan Budidaya Ikan Mas dan Mina Padi. Program Nasional Agribisnis Pedesaan. Makassar. 227 hal.

Sahwan, F. 2002. Pakan Ikan dan Udang : Formulasi, Pembuatan, Analisis Ekonomi. Penebar Swadaya. Jakarta.

Sediaoetama, A.D. 2004. Ilmu Gizi. Jakarta : Dian Rakyat.

Setyono, H., Kusriningrum, Mustikoweni, T. Nurhajati, R. Sidik, Agustono, M. Arief, M. A. Al-Arief, A. M. Sahidu dan W. P. Lokapirnasari. 2007. Teknologi Pakan Hewan. Bagian Ilmu Peternakan Fakultas Kedokteran Hewan Universitas Airlangga. Surabaya.

Sheridan, A., M. 1987. Lipid Dynamics in Fish Aspects of Absorption, Transportation, Deposition and Mobilization. Department of Zoology, North Dakota State University, Kargo, ND 58105, USA.

Shurson,J., S. Noll, and J. Gohl. 2005. Corn By Product Diversity And Feeding Value To Non Ruminant. Proc. MN Nutr. Conf. p. 18-21. 
Sibbald, I.R. 1977. The Metabolizable Energy Values of some Feedingstuffs . Poultry Sci., 56 : 380-382.

Standar Nasional Indonesia. 1996. SNI Bungkil Kedelai. SNI. 01-4227-1996.

Soeseno, S. 1984. Dasar-dasar Perikanan Umum. Untuk Sekolah Pertanian Pembangunan. CV. Yasaguna. Jakarta. Hal 23-25.

Sugiarto, 1988. Teknik Pembenihan Ikan Mujair dan Nila. CV.Simplex. Jakarta.

Suprayudi, M.A., 2010. Bahan Baku Pakan Lokal. Tantangan Dan Harapan Akuakultur Indonesia. Disampaikan Dalam: Simposium Nasional Bioteknologi Akuakultur Iii. Ipb International Convention Center. Bogor.

Suryahadi, 1997. Strategi Pemanfaatan Sumber Daya dan Aplikasi Teknologi Pakan. Makalah Pembekalan KKN Mahasiswa IPB tahun 1997. Fakultas Petemakan IPB, Bogor.

Suyanto, S.R. 2009. Nila. Cetakan ke-XV. Penebar Swadaya. Jakarta. Hal 1-6.

Tangendjaja, B. 2008. Distiller's Dried Grains With Solubles (DDGS) Untuk Pakan. Balai Penelitian Ternak, Bogor.

Tangendjaja, B dan Wina, E. 2007. Limbah Tanaman dan Produk Samping Industri Jagung untuk Pakan. Balai Penelitian Ternak, Bogor.

Unit Layanan Pemeriksaan Laboratoris, Konsultasi dan Pelatihan, 2012, Fakultas Kedokteran Hewan, Universitas Airlangga

Wahyu, J. 2004. Ilmu Nutrisi Unggas edisi ke-5. Gadjah Mada University Press. Yogyakarta.

Watanabe T. 1988. Fish nutrition and mariculture. JICA text book. The general aquaculture course. Tokyo. 233pp.

Webster, C. D, and C. Lim. 2002. Nutrient Requierment and Feeding of Finfish for Aquaculture. United Kingdom : CABI Publishing.

Wirahadikusumah, 1985, Metabolisme Energi, Karbohidrat dan Lipid, Bandung, ITB.

Yasidi, F.,Aslan L.M, Asriyana., Rosmawati, 2005. Penuntun Praktikum Biologi Perikanan. Fakultas Perikanan Kelautan. Universitas Haluoleo. Kendari.

Yuwono, Edy. dan Purnama Sukardi, 2001. Fisiologi Hewan Air, CV. Sagung Seto, Jakarta, Indonesia. 